\title{
Creative thinking style and the discovery of entrepre- neurial opportunities in startups
}

Héctor Montiel Campos ${ }^{1}$ Francesc Solé Parellada ${ }^{2}$ Madet Ruiseñor Quintero ${ }^{3}$ Francisco Alfonso Aguilar Valenzuela ${ }^{4}$

${ }^{1}$ Universidad de las Américas Puebla , e-mail: hector.montiel@udlap.mx

${ }^{2}$ Universidad Politécnica de Cataluña, e-mail: francesc.sole@upc.edu

${ }^{3}$ Universidad Ramon Llull, e-mail: madet.ruisenor@esade.edu

${ }^{4}$ Centro de Investigación en Alimentación y Desarrollo, e-mail: aaguilar@ciad.mx

\section{KEYWORDS}

Creativity.

Opportunity, startups,

Entrepreneurship.

Founder-manager.

Received 29.10.14

Revised 30.03.15

Accepted 06.04.15

DOI:10.7867/1980-4431.2015v20n1p3-12

ISSN 1980-4431

Double-blind review

\section{ABSTRACT}

It is generally accepted that the concept of entrepreneurship seeks to understand how opportunities are identified and exploited. However, academic research so far has been mainly conceptual. Consequently, it has been suggested that scholars in this field of research should be more concerned about the origin and nature of opportunities rather than their characteristics. The objective of this research was to explore the relationship between the creative thinking style used by the founder-manager and the type of entrepreneurial opportunity that he/she decided to exploit. This research empirically tested two types of creative thinking (adaptive and innovative) and two types of entrepreneurial opportunity (Kirznerian and Schumpeterian). Both perspectives have opposing views. To explore this relationship, a gradual statistical analysis of the answers provided by 116 founder-managers of startups was compiled. First, a confirmatory factor analysis was performed in order to test scale's components. Second, correlation and regression analysis were used to analyze the relation between creative thinking and entrepreneurial opportunity. Results indicate that the thinking style that prefers to generate original ideas when confronted with a problem is strongly related to the innovative entrepreneurial opportunities, requiring intellectual creativity from the manager leading to a wealth of new information. Similarly, a thinking style that prefers exhaustive, accurate and methodical styles is related to the incremental entrepreneurial opportunities, relying on existing patterns to make things better. Other relationships between the creative thinking style and the entrepreneurial opportunity are identified in the document, as well as theoretical and practical implications of each of them.

\section{Introduction}

Creativity is a trait that individuals, groups and organizations possess that consists in a thinking process associated with imagination, intuition, perspicacity, inspiration, and which leads to the generation of ideas (GEORGE; ZHOU, 2007; ZHOU; HIRST; SHIPTON, 2010). Creativity is a process of divergent and convergent thinking (HENNESSEY; AMABILE, 2010). Sternberg (1999) mentions that creativity is the capacity of making something novel as well as useful. Creativity is a quality that is often attributed to entrepreneurs and has been described by Morris and Kuratko (2002) as the soul of entrepreneurship. Entrepreneurs use their creativity to design innovative solutions, in order to overcome resource limitations to market and make their new busi- nesses grow, or else, to identify entrepreneurial opportunities (FILLIS; RENTSCHLER, 2010). Creativity plays an important role in the entrepreneurial process, thus allowing entrepreneurs to participate in an increasingly competitive and dynamic environment (ZHOU, 2008).

The entrepreneurial opportunities topic is an important research area in the entrepreneurship field (CASSON; WADESON, 2007). Identifying entrepreneurial opportunities is a contributing factor in the economic sustainability of enterprises, especially for startups. Launching opportunities for new products or services arise from the changing environment, and more creative individuals have been found to be more likely to recognize entrepreneurial opportunities (HEINONEM; HYTTI; STENHOLM, 2011). Due to the inherent differences entrepreneurs mention while interact- 
ing with changing situations, entrepreneurial opportunities are not easy to describe due to their subjective nature (ECKHARDT; SHANE, 2003). In this regard, it turns out that creativity is not something homogeneous either (UNSWORTH, 2001; PRETORIOUS; MILLARD; KRUEGER, 2005). Consequently, creativity may be seen as the ability entrepreneurs have to conceive new combinations of independent elements that can generate a new product or an improved product, service, process, or a practice which adds value when compared to what already existed (DAYAN; ZACCA; BENEDETTO, 2013).

In recent years, a special interest in understanding how entrepreneurs discover opportunities has emerged, nevertheless, little attention has been paid to the elements that lead entrepreneurs into becoming more creative (SHALLEY; ZHOU; OLDHAM, 2004). The former takes to argue that the entrepreneur's creative capacity impacts the entrepreneurial process, specifically in the generation of innovative solutions that satisfy the market's needs (PRETORIOUS, MILLARD; KRUEGER, 2005). That is why the goal of this research is to identify the existing relation between creative thinking style and the type of entrepreneurial opportunity identified by the entrepreneur, which foster his/her business' growth.

To achieve this research objective, this paper is structured as follows: after the introduction, the theoretical framework is developed, and afterwards, the methodology used for this project is described. The research outcomes are shown in a following section so that, lastly, general comments are made and the project's main conclusions are shown.

\section{Theoretical framework}

Given the relevance of creativity, a series of theories and models have been developed, which help to further know its nature, in such a way that a greater and better impact on it can be achieved. Osborn (1963) was one of the pioneers by introducing the Creative Problem Solving, a cognitive model that describes the different stages of the creative thinking through which it can deliberately move to solve complex problems. Osborn's work detonated the development of further proposals, for example Kirton's (1976) theory, the Buffalo Creative Process Inventory (MACKINNON, 1978), the Four Sight Model (ISAKSEN; DORVAL; TREFFINGER, 1994), and the Creative Problem Solving Profile (BASADUR; GRAEN; WAKABAYASHI, 1990). All these proposals aim to better understand the creative process.

In 1976 Kirton developed a theory of cognitive basis on creativity in which, instead of focusing on how creative a person is, the focus is on the expression of creativity through qualitatively dif- ferent cognitive styles. Cognitive styles refer to the different ways in which people prefer to organize and process information (MESSICK, 1984). Kirton's Theory (1976; 2003) addresses the creativity type or style that people prefer to exhibit. Kirton's theoretical continuum goes from a more adaptive orientation, which is a preference to work within the current model or system to be improved, to an innovative orientation, which relates to a preference for the challenge or the going beyond the current model or system. Kirton mentions that both styles have the same value and, as such, one style isn't more important than the other.

Unlike other creativity theories, which focus on understanding it as a quantifiable ability, Kirton's knowledge-based theory explores the different ways in which creativity is expressed. Kirton developed a measurement of 32 items, the Kirton Adaption-Innovation Inventory (KAI), to evaluate people's preference along the adaptor-innovator continuum. The measurement generates four scores: three scores in variables and one total score. One variable is called Sufficiency of Originality (SO), which evaluates the degree to which a person prefers to generate original ideas when faced with a problem (an innovative trend), or else, to focus on a few more viable ideas (an adaptive trend). Another variable considers people's preference to be thorough, precise and methodical (an adaptive trait). This variable is called Efficiency (EFF). The third variable is called Rule/Group Conformity (RGC), which measures a person's preference to respect (adaptive), or to resist rules and authority (innovative). The combination of the three variables generates a person's general preference between adaptive and innovative. The total score ranges between 32, the adaptation's pole, to 160 , the innovation pole.

Several studies with different aims have noted the benefits of the KAI scale. For example, some research projects have studied the interaction between the creative styles defined by Kirton and the creative process in problem solution (MCFADZEAN, 1998; PUCCIO, 1999; PUCCIO; WHEELER; CASSANDRO, 2004; ISAKSEN; TREFFINGER, 2004). Other projects have explored the link between cognitive styles and personality (ISAKSEN; LAUER; WILSON, 2003; SHALLEY; ZHOU; OLDHAM, 2004; PUCCIO; GRIVAS, 2009). Despite the various studies in which the KAI scale has been used, there are those who do not share the distinction of its creative styles, preferring a conceptual analysis of various regards of novelty in problem solution (KAUFMANN, 2003; 2004).

Shane and Venkataraman (2000) mention that people differ in their ability to identify entrepreneurial opportunities, that is, to combine concepts and information in a novel way. From Shane 
and Venkataraman's (2000) proposal, the relevance of understanding how entrepreneurial opportunities are discovered and exploited in the entrepreneurship field has been accepted. McMullen, Plummer and Acs (2007) mention that in recent years, literature on the nature of opportunities has multiplied, although the later has mainly grown conceptually.

Shane (2003) defines an entrepreneurial opportunity as "a situation in which a person can create a new means-ends framework for recombining resources that the entrepreneur believes will yield a profit" (p. 18). Shane mentions that, to date, two explanations about the discovery of opportunities are identified, which are central in the entrepreneurship field, but at the same time are opposite. These are known as the Kirznerian (1973) and the Schumpeterian (1934) views.

Essentially, what makes Kirzner's and Schumpeter's view different is knowing if the existence of entrepreneurial opportunities involves a differential access to existing information, or the introduction of new information. Kirzner (1973; 1999) argues that the existence of entrepreneurial opportunities only requires a differential access to existing information, that is, people benefit from existing information asymmetries in the market. Kirzner (1973) explains that people use information that they already own to form a guess about the efficient use of resources. This guess is not always correct and it causes shortages or surpluses in the market (KIRZNER, 2009), which paves the way for new opportunities to emerge that someone may identify (TANG; KACMAR, BUSENITZ, 2012). In contrast, Schumpeter (1934) emphasizes that the new information is what explains the existence of entrepreneurial opportunities. Schumpeter argues that changes in technology, politics, regulation, macroeconomic agents, and social trends create new information that people may use to propose new ways to combine resources.

Literature shows that the Kirznerian and Schumpeterian views represent different types of opportunities and that both are present in the economy at the same time (ECKHARDT; SHANE, 2003; MCMULLEN; PLUMMER; ACS, 2007). Shane (2003) performs a comparative analysis of both types of opportunity aiming to emphasize the different effects on the economic activity. Schumpeterian opportunities emerge from destabilizing forces, while Kirznerian opportunities emerge from equilibrating forces. Ergo, Kirznerian opportunities strengthen the established way of doing things, whilst Schumpeterian opportunities disrupt the existing system. In this line of reasoning, the disrupting nature of Schumpeterian opportunities makes them more relevant, as well as rare, compared to Kirznerian opportunities (SHANE, 2003). Besides, Schumpeterian opportunities are innova- tive and move away from existing knowledge, while opportunities are not as innovative and replicate existing organizational patterns. Whatever kind of opportunity, entrepreneurship consists in the perception of previously unnoticed profit opportunities and this argument suggest that the most opportunities are Kirznerian, where "opportunities" are essentially synonymous with arbitrage possibilities (MCCAFFERY, 2014).

There are few research articles that have inquired about the differentiation between Kirznerian and Schumpeterian opportunities. For instance, Craig and Johnson (2006) in a study involving 103 Engineering and Business students identify that Engineering students have a greater inclination towards Schumpeterian opportunities. In another document, Samuelson and Davidsson (2009) identify in 259 individuals that the process of creating an enterprise is different when it comes to innovation and imitation. De Jong and Marsili (2010, 2011) identify in 184 high-tech small business owners that Schumpeterian opportunities are correlated with an innovative behavior, an ambition for growth and a strategic emphasis on new product development. In contrast, Kirznerian opportunities were associated with exploiting the current demands.

In the light of the above, the intention of this research was to broaden the research on Kirton and Shane theories by exploring the link that exists between the type of creativity (adaptiveinnovative) and the type of entrepreneurial opportunity (Kirznerian-Schumpeterian) that an entrepreneur identifies. Thus, at a higher level of this research, an analysis of the creative qualities associated with the type of entrepreneurial opportunity was proposed. Beyond the chance of using a popular scale such as KAI for research purposes, the types of entrepreneurial opportunity described by Shane (2003) make it possible to identify a series of cognitive preferences for those opportunities.

\section{Methodology}

\subsection{Participants and data collection}

The empirical study was performed with information that was collected through a questionnaire that was sent to entrepreneurs in Mexico. Although the survey addresses the foundermanager, establishing criteria that attempted to set relative equality of conditions in their answers was considered important. Among the criteria were that the startup had to be new, that is, it should have started operations three and a half years at the most when the survey was implemented (GEM, 2013). Likewise, the startup should have belonged to the manufacturing sector and had 30 employees at the most so that it would be considered as a Small Company, according to Mexico's Ministry of Economy. Initially 872 
startups were identified that possessed those characteristics in the Mexican Information System, and from which greater information could be retrieved.

Previous to the definite data collection, a test with five founder-managers was performed in order to identify if the wording of the questionnaire was appropriate. The observations made were incorporated in the final version of the questionnaire. In essence, adjustments consisted only of making the wording of some items more understandable, without modifying the aim of each one of them. The final questionnaires were sent electronically between June 2013 and January 2014. The questionnaires were addressed to the foundermanager of the startup along with a letter explaining the goal of the research. The entrepreneur was asked to evaluate the opportunity he/she was commercially exploiting at the time, in order to contrast two theories.

Lastly, 116 questionnaires were received, which represented a reply of approximately 13\%. The reply percentage is low, but it is consistent with this data collection technique. An analysis was performed to identify if a difference or a bias existed among those who replied the questionnaire at the beginning or at the end of the collection period (ARMSTRONG; OVERTON, 1977). The results confirmed there was no bias, therefore, the questionnaires could be combined.

\subsection{Measurements}

To measure the creative thinking style, Kirton's $(1976 ; 2003)$ theory was used, specifically the KAI scale derived from this theory. The KAI scale consists of 32 sentences, 13 of which measure the SO, 7 measure the EFF, and 12 measure the RGC. For each sentence, the respondent indicates in a five-point Likert scale to what degree he/she agrees with the given sentence.

The type of entrepreneurial opportunity was measured using Shane's (2003) theory, particularly De Jong and Marsili's (2010, 2011) proposal who developed and validated a 5 dimension scale, through which it seeks to identify the type of opportunity (Kirznerian or Schumpeterian): 1. Arbitrage-innovation; 2. Equilibrating-disequilibrating; 3. Discovery-creation; 4. Common-rare 5. No new information-requires new information. Each dimension consists of two bipolar sentences that are evaluated in a five-point scale, indicating towards which pole there is a greater description of its reality.

\subsection{Data analysis}

The data analysis was performed gradually, in order to improve the research results. First, the reliability and adequacy of each scale was analyzed from the sample's nature. The reliability was accepted through Cronbach's alphas in each of the scale's components. Later, a confirmatory factor analysis was performed in order to test if the dimensions that integrated the creative thinking style and the type of entrepreneurial opportunity represented different dimensions. The model was evaluated using the $c^{2} / d f$, Goodness-of-Fit Index (GFI) (JÖRESKOG; SÖRBOM, 1996), and the Comparative Fit Index (CFI) (BENTLER, 1992). The threshold for $c^{2} / d f$ should be less than three or less than two in a more restrictive sense (PREMKUMAR; KING, 1994). The GFI and CFI values should be above 0.90 (JÖRESKOG; SÖRBOM, 1996). Once the scales were validated, a correlation analysis was performed to examine the relationships between the variables of both scales. Lastly, a regression analysis was used to analyze the relation among creative thinking style and entrepreneurial opportunity type variables.

\section{Results}

Regarding the reliability analysis and following Hair et al.'s, (2007) recommendations, the $\mathrm{SO}$, EFF, and RGC variables, which represent the creative thinking style were reliable enough (Cronbach's a $>0.70$ and mean correlation > 0.40). As for the type of entrepreneurial opportunity, each dimension was also reliable enough, although each dimension had two items.

In the confirmatory factor analysis, the creative thinking style resulted in good fit: $\mathrm{c}^{2} / d f=$ 2.61, GFI $=.913$, CFI $=0.940$. All the factors loaded into acceptable and significant ranges in $p$ $=0.001$, whose range was between 0.74 and 0.85 indicating a convergent validity (ANDERSON; GERBIN, 1988). The average variance was 0.75 , which is slightly above the threshold suggested by Bagozzi and Yi (1988). Regarding the type of entrepreneurial opportunity, the model also showed an acceptable adjustment: $\mathrm{c}^{2} / d f=2.88$, GFI $=.920, \mathrm{CFI}=0939$. All the factors loaded into acceptable and significant ranges in $p=0.001$, from 0.77 to 0.83 indicating a convergent validity. The average variance was 0.71 . 
Table 1. Descriptive Statistics for creative thinking style and entrepreneurial opportunity type $(\mathrm{N}=116)$

\begin{tabular}{|c|c|c|c|c|}
\hline Variable & $\mathrm{M}$ & SD & Minimum & Maximun \\
\hline \multicolumn{5}{|l|}{ Creative Thinking Style } \\
\hline Sufficiency of Originality & 3.94 & 1.14 & 26 & 55 \\
\hline Efficiency & 3.72 & 1.33 & 15 & 29 \\
\hline Rule/Group Conformity & 3.55 & 1.32 & 26 & 45 \\
\hline \multicolumn{5}{|l|}{ Entrepreneurial Opportunity Type } \\
\hline Arbitrage-Innovation & 4.04 & 0.96 & 2 & 10 \\
\hline Equilibrating-Disequilibrating & 3.84 & 0.97 & 3 & 10 \\
\hline Discovery-Creation & 3.97 & 1.02 & 2 & 10 \\
\hline Common-Rare & 3.77 & 0.89 & 2 & 10 \\
\hline $\begin{array}{l}\text { No new information-Requires } \\
\text { new information }\end{array}$ & 3.83 & 1.07 & 2 & 10 \\
\hline
\end{tabular}

Source: Developed by the authors.

In regards to the general preference which helps identify the KAI scale, between adaptive and innovative, the analyzed sample earned an average value of 127.1 , which indicates a greater orientation towards innovation.

Table 1 shows the descriptive statistic of the participating founder-managers in the study, who solved sentences to identify the creative thinking style and the type of entrepreneurial opportunity. The relation among the variables was analyzed through the correlation coefficients calculation, which can be observed in Table 2. From the 15 correlations, 8 are statistically significant. It is interesting to observe that the variable $\mathrm{SO}$ of the creative thinking style is practically the only one that correlates positively and significantly with all the variables of the entrepreneurial opportunity type. Among these correlations, the one between the SO and Arbitrage-Innovation $(r=0.41, p<$ $0.05)$, as well as the one between SO and Discovery-Creation $(r=0.34, p<0.01)$ excel. Regarding the EFF variable, the correlation between it and Arbitrage-Innovation, as well as Common-Rare are significant and negative $(r=-0.22, p<0.01 \mathrm{y}$ $r=-0.25, p<0.05$, respectively). Lastly, the RGC variable shows a correlation that is also significant with the Equilibrating-Disequilibrating variable $(r$ $=-0.31, p<0.01$ ).

Table 2. Correlation Coefficients between creative thinking style and entrepreneurial opportunity type $(\mathrm{N}=116)$

\begin{tabular}{|c|c|c|c|c|c|}
\hline \multirow[b]{2}{*}{$\begin{array}{l}\text { Creative thinking } \\
\text { style }\end{array}$} & \multicolumn{5}{|c|}{ Entrepreneurial Opportunity Type } \\
\hline & $\begin{array}{l}\text { Arbitrage- } \\
\text { Innovation }\end{array}$ & $\begin{array}{l}\text { Equilibrating- } \\
\text { Disequilibrating }\end{array}$ & $\begin{array}{l}\text { Discovery- } \\
\text { Creation }\end{array}$ & Common-Rare & $\begin{array}{l}\text { No new infor- } \\
\text { mation-Requires } \\
\text { new information }\end{array}$ \\
\hline $\begin{array}{l}\text { Sufficiency of } \\
\text { Originality }\end{array}$ & $0.41 *$ & 0.29 & $0.34 * *$ & $0.21 *$ & 0.27 \\
\hline Efficiency & $-0.22 * *$ & $0.12 *$ & -0.06 & $-0.25 *$ & $-0.13 * *$ \\
\hline $\begin{array}{l}\text { Rule/Group Con- } \\
\text { formity } \\
* p<0.05, * * p<\end{array}$ & $-0.10^{*}$ & $-0.31 * *$ & -0.12 & $-0.15^{*}$ & 0.09 \\
\hline
\end{tabular}

Source: Developed by the authors

A correlation coefficient analysis was performed among the variables in the KAI scale. The results indicated that the former were significant in all comparisons (SO-EFF, $r=0.33$; SO-RGC, $r$ $=0.41$; EFF-RGC, $r=0.47$ ). From this, a regression analysis was performed to analyze the relation between creative thinking style variables and those from entrepreneurial opportunity type by removing the shared variance among the KAI scale variables. In Table 3, the standardized re- gression (beta) coefficients for each variable of the KAI scale can be observed in relation with the five dimensions of the entrepreneurial opportunity type, as well as the total variance explained (see $\mathrm{R}^{2}$ ).

With this analysis, six coefficients were identified. Out of the three variables of the KAI scale, the SO variable generated the most significant coefficients, all being positive. The positive coefficient with Arbitrage-Innovation indicates a 
clear relation with the type of opportunity identified by the entrepreneur. In this case, the entrepreneur portrays a clear tendency towards identifying non-conventional opportunities. The opportunity is not a true reflection of what exists, but of something that perhaps has not been experienced yet and, therefore, is unknown. In this sense, the entrepreneur must be a person who enjoys generating new ideas and experimenting with new possibilities that reflect his/her preference for change. This approach leads the entrepreneur to defy the existing paradigms and to rely more on creativity. Opportunity identification implies that entrepreneurs use creative processes to perceive new ideas and to put them into action (DIMOV, 2007). One would assume that creativity is a factor that has been extensively researched in an area that focuses on identifying new opportunities. However, this is not the case and the existing empirical findings are mixed or non-conclusive. DeTienne and Chandler (2004) showed that creativity is positively related to opportunity identification while Hansen, Lumpkin and Hills (2011) found only partial support for their hypothesis that creativity underlies opportunity identification. On the other hand, SO also shows a positive and significant coefficient with Discovery-Creation, which indicates that the other opportunities the entrepreneur is identifying are not obvious in benefits, in other words, the entrepreneur is not finding the opportunities, but, once the first aspects of the opportunity are identified which make it attractive to his/her interests and goals, the entrepreneur decides to work on these first findings in such a way that he/she develops or creates the opportunity. Evidently, this also helps understand the significant coefficient SO has with No new information-Requires new information. Due to the result obtained, it can be established that originality in the opportunity the entrepreneur develops demands him/her to get new information, which may not be within his/her reach. This outcome does not indicate exactly the type of information needed, but it does unveil that the information or knowledge that the entrepreneur has is not enough. This result is consistent with Gielnik et al., (2012), who use an experimental design to test the hypothesis that diversity of information moderates the effect of divergent thinking on business idea generation.

Table 3. Standardized Regression Coefficients between creative thinking style and entrepreneurial opportunity type (N=116)

\begin{tabular}{|c|c|c|c|c|c|}
\hline \multirow{2}{*}{$\begin{array}{l}\text { Creative thinking } \\
\text { style }\end{array}$} & \multicolumn{5}{|c|}{ Entrepreneurial opportunity type } \\
\hline & $\begin{array}{c}\text { Arbitrage- } \\
\text { Innovation }(t)\end{array}$ & $\begin{array}{c}\text { Equilibrating- } \\
\text { Disequilibrating }(t)\end{array}$ & $\begin{array}{l}\text { Discovery- } \\
\text { Creation }(t)\end{array}$ & $\begin{array}{c}\text { Common-Rare } \\
(t)\end{array}$ & $\begin{array}{c}\text { No new infor- } \\
\text { mation-Requires } \\
\text { new information }(t)\end{array}$ \\
\hline $\begin{array}{l}\text { Sufficiency of } \\
\text { Originality }\end{array}$ & $\begin{array}{l}0.31 * \\
(3.22)\end{array}$ & $\begin{array}{c}0.13 \\
(1.38)\end{array}$ & $\begin{array}{l}0.27 * \\
(2.68)\end{array}$ & $\begin{array}{c}0.09 \\
(0.53)\end{array}$ & $\begin{array}{c}0.23 * * \\
(2.67)\end{array}$ \\
\hline Efficiency & $\begin{array}{l}-0.21 * * \\
(-2.35)\end{array}$ & $\begin{array}{l}-0.08 \\
(-0.32)\end{array}$ & $\begin{array}{l}-0.25^{*} \\
(-2.67)\end{array}$ & $\begin{array}{l}-0.15 \\
(-1.32)\end{array}$ & $\begin{array}{l}-0.12 \\
(-1.17)\end{array}$ \\
\hline $\begin{array}{l}\text { Rule/Group Con- } \\
\text { formity }\end{array}$ & $\begin{array}{l}-0.22 * \\
(-2.14)\end{array}$ & $\begin{array}{l}-0.18 \\
(-1.17)\end{array}$ & $\begin{array}{c}0.12 \\
(1.22)\end{array}$ & $\begin{array}{l}-0.06 \\
(-0.55)\end{array}$ & $\begin{array}{l}-0.15 \\
(-1.20)\end{array}$ \\
\hline $\mathrm{R}^{2}$ & 0.19 & 0.09 & 0.11 & 0.11 & 0.13 \\
\hline F-value & 7.23 & 3.40 & 4.47 & 4.64 & 5.06 \\
\hline
\end{tabular}

Source: Developed by the authors.

On the other hand, the EFF dimension of the creative thinking style shows two relations that are negative. The relation with ArbitrageInnovation indicates that when the entrepreneur wants to be methodic, he/she sticks more towards identifying small existing variants of entrepreneurial opportunities, that is, in this case, the entrepreneur uses an increasing creativity relying on existing patterns, so he/she may be figuring out how to do things better. In addition to this, the negative relation that also exists with DiscoveryCreation helps reinforce the impression that precision, comprehensiveness, and the methodical, slow the entrepreneur's disruptive facet when identifying an entrepreneurial opportunity. Lastly, the RGC dimension also shows a negative coefficient with Arbitrage-Innovation, indicating that the entrepreneur, when being more respectful of the status quo leans towards the incremental and becomes less tolerant to change so that novelty seems very challenging and, therefore, may be avoided or rejected.

The combination of these results, three positive SO, two negative EFF, and one negative RGC with three dimensions of the type of entrepreneurial opportunity leads to remark that the goal of the investigation has been accomplished, since a greater relation between an innovative thinking 
style and the identification of more Schumperian entrepreneurial opportunities is detected.

\section{Discussion and implications}

The results of this research show how the entrepreneurial opportunity type aligns with the creative thinking styles and how these statistically significant relationships appear in the expected theoretical sense. In particular, a clear relationship between the SO variable with the Shumpeterian type opportunities emerges. It is not surprising that people with a high degree of originality and useful sense of things relate with innovation, the disequilibrating, creation, the rare, as well as with the need to obtain new information. In this perspective, Shane and Nicolaou (2015) confirmed that people with creative personalities are more likely than others to identify business opportunities and start businesses. The EFF variable shows a qualitatively different approach, which causes the entrepreneur not to leave aside elements such as productivity, an element that looks very favored by organizational routines. The enterprise will always look for a way to achieve a better and greater performance, for which it will use its best practices, but results show that this regard pulls more towards Kirznerian opportunities, that is, opportunities of the incremental type. In this situation, the entrepreneur will select entrepreneurial opportunities which are better, considering the circumstances and the moment its business is facing. Under certain circumstances, it will be possible to identify and work on more innovative opportunities, or else, more conventional ones. On the other hand, we find the RGC variable, which relates more evidently with the balancing nature of opportunities. In other words, people's attachment to a greater plurality and inclusion for decision making pulls towards Kirznerian opportunities. This variable may restrict the entrepreneur's innovative capacity, since he/she must consult, and if so, consider the group's stance, if that is his/her approach. This may give clue to consider that the leadership style influences the group's creative capacity.

On the other hand, the regression analysis clearly shows that the three variables of the creative thinking style have a better relationship with the arbitrage-innovation dimension of entrepreneurial opportunities. The SO variable relates with innovation, and the EEF and RGC variables relate with arbitrage. The combination of these three variables explains $19 \%$ of the arbitrage-innovation dimension. One more time, the results show that the variables may play in opposite senses in Kirton's KAI scale. In other words, when facing the same opportunity, the entrepreneur will be thinking in an original way, but, at the same time, he/ she must be thinking about how to do it, without this lessening the attractiveness of the identified opportunity. It is exactly this balance, where the KAI scale identifies that creativity must not only result in something original, but in something useful as well.

Another issue that the regression analysis also reveals is that the SO and the EFF variables have a good relationship with the Discoverycreation dimension. In this relationship, the SO variable pulls towards a Schumpeterian opportunity while the EFF pulls towards a Kirznerian opportunity. This result may indicate that the entrepreneur has a certain ability to identify the pragmatic side of entrepreneurial opportunities. That is, the entrepreneur is sensitive to the information that surrounds him/her, in a way that it helps him/ her identify entrepreneurial opportunities considering previous experience. He/she does not stop being interested in what is new, which is established in the existing relation between $\mathrm{SO}$ and creation.

Lastly, the SO variable again shows a good relationship towards the Schumpeterian type of opportunities, which now becomes evident with the "requires new information" dimension. This relationship may indicate that the entrepreneur, being more interested in novelty, must then use new information. This may indicate, in an indirect way, that the entrepreneur's mindsets are enough for entrepreneurial opportunities of the Kirznerian type, but not for the Schumpeterian type. Our results are complementary to other approaches to analyzing the role of creativity in entrepreneurship. Our study does not challenge the importance of creative thinking style for opportunity recognition. It follows the approach of Kozbelt, Beghetto and Runco (2010), who argue that to truly explain creativity one must also delve more deeply into understanding people. Besides, creativity research and theory, argue that creativity vary from domain to domain (BAER, 2010).

\section{Limitations and future research}

In light of the obtained results of this research, it is necessary to consider some limitations, which does not detract the findings. First, it is important to consider the limitation that may generate the entrepreneurial opportunity evaluated by the entrepreneur. It would be interesting to standardize an opportunity, which could be Kirznerian or Schumpeterian, in such a way that, through an analysis of the former, a greater tendency towards the increasing or disruptive in its thinking style could be identified. This task may be considered in future research projects.

On another hand, and as a second topic to reflect on, it would be interesting to analyze the relationship that may exist between the types of entrepreneurial opportunities and those of entrepreneurial alertness. This relationship could gener- 
ate information that may help identify certain qualities in the environment analysis that lead an entrepreneur towards a certain type of opportunity. The information analysis and the environment analysis with the entrepreneurial opportunity may help identify new context agents in which it may impact.

Finally, one may not stop considering that Shane's theory and his proposal about two types of opportunities has been little explored. The outcomes here presented may contribute to further work in this research stream, in such a way that it may link this classification with other type of variables, as it was done in this research. One must not forget that the type of entrepreneurial opportunity could define different business processes, and as a consequence, entrepreneurs' profiles that are also different. In this point of view, Bledow, Rosing and Frese (2013), argue that creativity is influenced by the dynamic interplay of positive and negative affect. It is worthwhile to continue working on this research stream.

\section{Conclusion}

The purpose of this research was to know the relationship that exists between the creative thinking style and entrepreneurial opportunities in the context of startups. An empiric research was performed with 116 founder-managers to identify the aforementioned relationship with the entrepreneurial opportunity that they were currently exploiting. The results suggest that there is a clear relationship between a creative thinking style of the innovative kind with entrepreneurial opportunities of the Schumpeterian kind. In this relationship, the entrepreneur looks for originality, which demands greater innovation, creativity and new information. By the former, this result supports the supposition that the greater the originality, the more it is necessary to find links with other areas or elements that were not initially considered. Besides, the results show that the exhaustive and methodical, as well as following the rules or the authority, lead towards patterns or schemes already established, that is, Kirznerian opportunities, in such a way that what is pursued is to do things better, not differently.

\section{References}

ANDERSON, J. C.; GERBING， D. W. Structural Equation Modeling in Practice: A Review and Recommended Two-Step Approach. Psychological Bulletin, v. 103, n. 3, p. 411-423, 1988.

ARMSTRONG, J. S.; OVERTON, T. S. Estimating nonresponse bias in mail surveys. Joumal of Marketing Research, v. 14, n. 3, p. 396-402, 1977.
BAER, J. Is creativity domain specific? In: Kaufman, J. C.; Sternberg, R. J. (Eds.), Handbook of Creativity. Cambridge University Press: Cambridge, 2010.

BAGOZZI, R. P.; YI, Y. On the Evaluation of Structural Equation Models. Journal of the Academy of Marketing Science, v. 16, n. 1, p. 74 -94, 1988.

BASADUR, M.; GRAEN, G.; WAKABAYASHI, M. Identifying individual differences in creative problem solving style. Journal of Creative Behavior, v. 24, p. 111-131, 1990.

BENTLER, P. M. EQS Structural Equations Program Manual. Los Angeles: BMDP Statistical Software, 1992.

BLEDOW, R.; ROSING, K.; FRESE, M. A dynamic perspective on affect and creativity. Academy of Management Journal, v. 56, n. 2, p. 432-450. 2013.

CASSON, M.; WADESON, N. The discovery of opportunities: extending the economic theory of entrepreneur. Small Business Economics, v. 28, p. 285-300, 2007.

CRAIG, J. B. L.; JOHNSON, D. Establishing individual differences related to opportunity alertness and innovation dependent on academiccareer training. Journal of Management Development, v. 25, n. 1, p. 28-39, 2006.

DAYAN, M.; ZACCA, R.; BENEDETTO, A. D. An exploratory study of entrepreneurial creativity: its antecedents and mediators in the context of UAE firms. Creativity and Innovation Management, v. 22, n. 3, p. 223-240, 2013.

DETIENNE, D. R.; CHANDLER, G. N. Opportunity identification and its role in the entrepreneurial classroom: a pedagogical approach and empirical test. Academy of Management Leaming and Education, v. 3, n. 3, p. 242-257. 2004.

DE JONG, J. P. J.; MARSILI, O. Schumpeter versus Kirzner: An empirical investigation of opportunity types. Working paper. EIM Research Reports. RSM Erasmus University, 2010.

DE JONG, J. P. J.; MARSILI, O. Schumpeter versus Kirzner: Comparing two types of opportunity (summary). Frontiers of Entrepreneurship Research, 31(15), Article 6, 2011.

DIMOW, D. Beyond the single-person, single-insight attribution in understanding entrepreneurial opportunities. Entrepreneurship Theory and Practice, v. 31, n. 5, p. 713-731. 2007.

ECKHARDT, J. T.; SHANE, S. Opportunities and entrepreneurship. Journal of Management, v. 29, n. 3, p. 333-349, 2003.

FILLIS, I.; RENTSCHLER, R. The role of creativity in entrepreneurship. Joumal of Enterprising Culture, v. 18, n. 1, p. 49-81, 2010.

GEM. Global Entrepreneurship Monitor 2013 Global Report. Global Entrepreneurship Research Association. London Business School, 2013. 
GEORGE, J.; ZHOU, J. Z. Dual tuning in a supportive context: Joint contributions of positive mood, and supervisory behaviors to employee creativity. Academy of Management Joumal, v. 50, p. 605-622, 2007.

GIELNIK, M. M.; FRESE, M.; GRAF, J.; KAMPSCHULTE, S. Creativity in the opportunity identification process and the moderating effect of diversity of information. Journal of Business Venturing, v. 27, n. 5, p. 559.576. 2012.

HAIR, J. F.; BLACK, W. C.; BABIN, B. J., ANDERSON, R. E. Multivariate data analysis. 7ed. Englewood Cliffs, New Jersey: Prentice Hall, 2007.

HANSEL, D. J.; LUMPKIN, G. T.; HILL, G. E. A multidimensional examination of a creativity-based opportunity recognition model. International Journal of Entrepreneurial Behaviour \& Research, v. 17, n. 5, p. 515-533. 2011.

HEINONEN, J.; HYTTI, U.; STENHOLM, $\mathrm{P}$. The role of creativity in opportunity search and business idea creation. Education and Training, v. 53, n. 8, p. 659-672, 2011.

HENNESSEY, B. A.; AMABILE, T. M. Creativity. Annual Review of Psychology, v. 61, p. 569-598, 2010.

ISAKSEN, S. G.; DORVAL， K. B.; TREFFINGER, D. J. Creative approaches to problem solving. Kendall/Hunt, Dubuque, IA, 1994.

ISAKSEN, S. G.; LAUER, K. J.; WILSON, G. V. An examination of the relationships between personality type and cognitive style. Creativity Research Journal, v. 15, p. 343-354, 2003.

ISAKSEN, S. G.; TREFFINGER, D. J. Celebrating 50 years of reflective practice: Versions of creative problem solving. Joumal of Creative Behavior, v. 38, p. 75-101, 2004.

JÖRESKOG, K. G.; SÖRBOM, D. LISREL 8: The Simplis Command Language. Chicago: Scientific Software International, 1996.

KAUFMANN, G. What to measure? A new look at the concept of creativity. Scandinavian Journal of Educational Research, v. 47, p. 235251, 2003.

KAUFMANN, G. Two kinds of creativitybut which ones? Creativity and Innovation Management, v. 13, n. 3, p. 154-165, 2004.

KIRTON, M. J. Adaptors and innovators: A description and measure. Journal of Applied Psychology, v. 61, p. 622-629, 1976.

KIRTON, M. J. Adaption-Innovation in the Context of Diversity and Change. Routledge: London, 2003.

KIRZNER, I. M. Competition and entrepreneurship. Chicago, IL, US: University of Chicago Press, 1973.

KIRZNER, I. M. Creativity and/or alertness: A reconsideration of the Schumpeterian entrepreneur. Review of Austrian Economics, v. 11, n. 12, p. 5-17, 1999.
KIRZNER, I. M. The alert and creative entrepreneur: A clarification. Small Business Economics, v. 32, p. 145-152, 2009.

KOZBELT, A.; BEGHETTO, R. A.; RUN$\mathrm{CO}, \mathrm{M}$. A. Theories of creativity. In: Kaufman, J. C.; Sternberg, R. J. (Eds.), Handbook of Creativity. Cambridge University Press: Cambridge, 2010.

MACKINNON, D. W. In search of human effectiveness. Creative Education Foundation, Buffalo, NY, 1978.

MCCAFFREY, M. On the theory of entrepreneurial incentives and alertness. Entrepreneurship Theory and Practice, v. , n. , p. 891-911, 2014.

MCMULLEN, J. S.; PLUMMER, L. A.; ACS, Z. J. What is an entrepreneurial opportunity? Small Business Economics, v. 28, p. 273-283, 2007.

MCFADZEAN, E. The creativity continuum: towards a classification of creative problem solving techniques. Creativity and Innovation Management, v. 7, p. 131-139, 1998.

MORRIS, M.; KURATKO, D. Corporate entrepreneurship: entrepreneurial development within organizations. Hartcourt College Publishers, Fort Worth, TX, 2002.

MESSICK, S. The nature of cognitive styles: Problems and promise in educational practice. Educational Psychologist, v. 19, p. 59-74, 1984.

OSBORN, A. F. Applied imagination: principles and procedures of creative problemsolving. Charles Scribner's Sons, New York, USA, 1963.

PREMKUMAR, G.; KING, W. R. Organizational Characteristics and Information Systems Planning: An Empirical Study. Information Systems Research, v. 5, n. 2, p. 75-109, 1994.

PRETORIOUS, M.; MILLARD, S.; KRUEGER, M. Creativity, innovation and implementation: management experience, venture size, life cycle stage, race and gender as moderators. South African Journal of Business Management, v. 36, p. 55-68, 2005.

PUCCIO, G. J. Creative problem solving preferences: Their identification and implications. Creativity and Innovation Management, v. 8, n. 3, p. 171-178, 1999.

PUCCIO, G. J.; WHEELER, R. A.; CASSANDRO, V. J. Reactions to creative problem solving training: Does cognitive style make a difference? Joumal of Creative Behavior, v. 38, p. 192-216, 2004.

PUCCIO, G. J.; GRIVAS, C. Examining the relationship between personality traits and creativity styles. Creativity and Innovation Management, v. 18, n. 4, p. 247-255, 2009.

SAMUELSON, M.; DAVIDSSON, P. Does venture opportunity variation matter? Investigat- 
ing systematic process differences between innovative and imitative new ventures. Small Business Economics, v. 33, p. 229-255, 2009.

SCHUMPETER, J. A. The theory of economic development. Cambridge, MA, US: Harvard University Press, 1934.

SHALLEY, C.; ZHOU, J.; OLDHAM, G. The effects of personal and contextual characteristics on creativity: Where should we go from here? Journal of Management, v. 30, p. 933-958, 2004.

SHANE, S.; VENKATARAMAN, S. The promise of entrepreneurship as a field of research. Academy of Management Review, v. 26, n. 1, p. 13-17, 2000.

SHANE, S. A general theory of entrepreneurship: The individual-opportunity nexus. Aldershot, UK: Edward Elgar, 2003.

SHANE, S.; NICOLAOU, N. Creative personality, opportunity recognition and the tendency to start businesses: A study of their genetic predispositions. Joumal of Business Venturing, v. 30, p. 407-419. 2015.

STERNBERG, R. Handbook of creativity. Cambridge University Press, New York, 1999.

TANG, J.; KACMAR, K. M.; BUSENITZ, L. Entrepreneurial alertness in the pursuit of new opportunities. Journal of Business Venturing, v. 27, p. 77-94, 2012.

UNSWORTH, K. Unpacking creativity. Academy of Management Review, v. 26, p. 289297, 2001.

ZHOU, Q. New look at creativity in the entrepreneurial process. Strategic Entrepreneurship Journal, v. 2, p. 1-5, 2008.

ZHOU, Q.; HIRST, G.; SHIPTON, H. Promoting creativity at work: the role of problemsolving demand. Applied Psychology, v. 61, p. 56 $-80,2010$. 